\title{
The impact of reduced tillage on some chemical properties of a clay loamy soil
}

\author{
Tomas Zukaitis ${ }^{1 *}$, Inga Liaudanskiene ${ }^{1}$ \\ ${ }^{1}$ Institute of Agriculture, Lithuanian Research Centre for Agriculture and Forestry (LRCAF), Instituto al. 1, Akademija, LT 58344 Kedainiai distr., \\ Lithuania \\ * PhD Tomas Zukaitis, zukaitis.tomas@gmail.com, ORCID iD: https://orcid.org/0000-0001-9263-3830
}

\begin{abstract}
Received: August 1, 2019

Accepted: April 16, 2020

Associated editor: B. Rutkowska

\section{Keywords}

Organic carbon Total nitrogen

Total phosphorus

Total potassium

Tillage

The quality, productivity and sustainability of soil as well as other terrestrial ecosystem renewable components is determined by the ability to accumulate organic matter. The aim of work is to evaluate the long-term effect of reduced tillage and its combinations with practices for soil improvement on soil organic carbon and macronutrients in different soil layers. The research was carried out in 2016-2017 at the Joniskelis Experimental Station of LRCAF on a clay loam. The following tillage systems were investigated: deep ploughing (DP) shallow ploughing (SP), ploughless tillage (PT), ploughless tillage with lime sludge ( $\mathrm{PT}+\mathrm{LS})$, ploughless tillage with green manure $(\mathrm{PT}+\mathrm{GM})$ and mulch without autumn tillage (NT+WM). The content of SOC, total N, P and K were measured in the soil samples, collected from 0-10, 10-20 and 20-30 cm layers. Compared to DP, the applied reduced tillage systems have led to an increase $S O C$ and $N_{\text {tot }}$ content in the $0-10 \mathrm{~cm}$ layer, but these decreased in deeper layers. Total and plant available $\mathrm{P}$, plant available $\mathrm{K}$ also increased in the $0-10$ $\mathrm{cm}$ layer due to additional improvement measures. The stratification of SOC and macronutrients was the least under DP.
\end{abstract}

\section{Introduction}

The Thematic Strategy on Soil (COM 231, 2006) obliges EU states to monitor and analyse the state of the soil, and to seek to use the soil in such a way that its physical, chemical and biological properties are not reduced and quality and overall productivity do not decrease._Recently, in many countries of the world, including the EU, emphasis has been placed on the decline of agrarian soils area and the deterioration of soil quality (COM 46, 2012). The quality, productivity and sustainability of soil as well as other terrestrial ecosystem renewable components (vegetation, fauna, microbiota) is determined by the ability to accumulate organic matter. SOM is a critical component of the soil-plant ecosystem, and depletion of SOM causes a loss in water holding capacity, poor aggregation, and acceleration in soil erosion, poor retention of applied nutrients, reduced soil biological and enzymatic activities (Ghani et al., 2003). The accumulation of soil organic matter (SOM), the main constituent of which is soil organic carbon (SOC), is the fixation of atmospheric $\mathrm{CO}_{2}$ through the process of photosynthesis into long-lived pools and storing in the soil. SOM is derived from a complicated mixture of fresh organic materials from plants, soil fauna, root exudates, microbial residues and chemically or physically protected substrates (von Lützow et al., 2007). The intense soil tillage combined with the simplified crop rotation and predominance of cereals together with the expansion of farming system based on crop production with reduced number of livestock intensifies the process of SOM degradation (Rutkowska and Pikuła, 2013). SOC stocks are affected not so much by climate change but by changes in land use (Brovkin et al., 2013). Tillage intensity reduction can improve soil quality (Van Groenigen et al., 2010), increase the carbon content in top soil layer (Ogle et al., 2005), result in greater soil biological activity and increase humus content (Slepetiene et al., 2010) but at the same time cause the loss of carbon in deeper soil layers (Blanco-Canqui and Lal, 2008). The impacts of tillage and organic residues on SOC are highly variable and difficult to predict, and their interactions need to be investigated under various soil, climate and cropping system conditions (Viaud et al., 2011). Different materials of various origin are used both as fertilizers and ameliorants in a heavy soils in order to preserve and increase SOC content as well as to improve negative soil properties, lime materials (Torkashvand et al., 2011; Hontoria et al., 2016) and cover crops for green manure (Tripolskaja and Šidlauskas, 2010) or for mulch (Saroa and Lal, 2003; Velykis and Satkus, 2018).

The aim of the research is to evaluate the impact of soil tillage intensity and additional improvement measures on some chemical properties in different layers of clay loam soil in longterm experiment. 


\section{Materials and methods}

Research was carried out at the Joniskelis Experimental Station of the Lithuanian Research Centre for Agriculture and Forestry, located in the northern part of Central Lithuanian's lowland $\left(56^{\circ} 21^{\prime} \mathrm{N}, 24^{\circ} 10^{\prime} \mathrm{E}\right)$ in the long-term experiment, established in 2006. The soil of the study site is Endocalcari-Endohypogleyic Cambisol (CMg-nw-can) (siltic, drainic). According to the data obtained before experiment, the plough horizon $(0-30 \mathrm{~cm})$ characteristics were as follows: texture - clay loam (22.7\% sand, $50.3 \%$ silt, and $27 \%$ clay), $\mathrm{pH}-6.6$, content of SOC-13,63 $\mathrm{g} \mathrm{kg}^{-1}$, total nitrogen $(\mathrm{N})-1,56 \mathrm{~g} \mathrm{~kg}^{-1}$, total phosphorus $(\mathrm{P})-0,54 \mathrm{~g} \mathrm{~kg}^{-1}$, plant available phosphorus $\left(\mathrm{P}_{2} \mathrm{O}_{5}\right)-59.73 \mathrm{mg} \mathrm{kg}^{-1}$, and potassium $\left(\mathrm{K}_{2} \mathrm{O}\right)-256.5 \mathrm{mg} \mathrm{kg}^{-1}$. The impact of reduced tillage as well as the combinations of reduced tillage with practices for soil improvement on soil organic carbon and macronutrients was investigated following the design: 1$)$ deep $(21-23 \mathrm{~cm}$ ) mouldboard ploughing (DP), 2) shallow (15-17 cm) mouldboard ploughing (SP), 3) ploughless tillage at 10-12 cm depth (PT), 4) ploughless tillage at 10-12 cm depth with lime sludge incorporation (PT+LS), 5) ploughless tillage at $10-12 \mathrm{~cm}$ depth with cover crops for green manure ( $\mathrm{PT}+\mathrm{GM})$, 6) no-tillage with cover crop for winter mulch (NT+WM). Research was conducted in the crop rotation: field pea (Pisum sativum L. (Partim) - winter wheat (Triticum aestivum L.) - spring oilseed rape (Brasica napus L.) - spring barley (Hordeum vulgare L.), which was spread over space and time. Cover crops were grown as follows: before field pea - a mixture of white mustard (Sinapis alba L.) and oilseed radish (Raphanus sativus L.), before spring oilseed rape - a mixture of field pea (Pisum sativum L. (Partim), common vetch (Vicia sativa L.) and blue lupine (Lupinus angustifolius L.), and before spring barley - oat (Avena sativa L.). The pre-crop straw was chopped during harvesting and incorporated into the soil at 6-8 cm depth; postharvest cover crops were sown after stubble cultivation. Lime sludge (calcium ( $\mathrm{CaO}-28,9 \%)$ containing waste from sugar industry), (7.0 $\mathrm{Mg} \mathrm{ha}^{-1}$ ) was incorporated three times for spring crops during the first stage of experiment (2007-2010) and once for spring barley in the second stage of experiment (2011-2014). Cover crop for winter mulch was left without any tillage in the autumn and its frost-killed residues covered the soil. All rotational crops were fertilized with $\mathrm{N}_{30} \mathrm{P}_{90} \mathrm{~K}_{60}$ (calculated as $\mathrm{P}_{2} \mathrm{O}_{5}$ and $\mathrm{K}_{2} \mathrm{O}$ ) before sowing. Nitrogen $(\mathrm{N})$, phosphorus $(\mathrm{P})$ and potassium was used as various particles of complex fertilizers. In spring the field pea was fertilized at $\mathrm{N}_{30}$ rate, winter wheat $-\mathrm{N}_{120}$, spring oilseed rape $-\mathrm{N}_{120}$, and spring barley $-\mathrm{N}_{60}$; for winter wheat and spring oilseed rape $\mathrm{N}$ fertilizers were given in two times. The field trial was laid out in a randomized single row design with four replicates. Each tilled sub-plot size was $16 \times 5=80 \mathrm{~m}^{2}$, of which 13 × $2.3=29.9 \mathrm{~m}^{2}$ was harvested.

The soil samples were collected annually after the main crop harvest, eight sub-samples per plot were taken randomly with a steel auger, and each soil sample core was separated into 0-10, 10-20 and 20-30 cm depth and combined across sub-samples by depth for each plot. All samples were air-dried, visible plant residues were removed manually, then samples were crushed and sieved through a 2-mm sieve. For the analysis of SOC, total nitrogen $(\mathrm{N})$, phosphorus $(\mathrm{P})$ and potassium $(\mathrm{K})$ con- tent an aliquot of the samples was passed through a $0.25-\mathrm{mm}$ sieve. Soil $\mathrm{pH}$ was determined by potentiometric method in $1 \mathrm{~mol} \cdot \mathrm{dm}^{-3} \mathrm{KCl}$ (soil to solution ratio 1:2.5). The content of SOC was determined by spectrophotometric measure procedure at the wavelength of $590 \mathrm{~nm}$ using glucose as a standard after wet combustion according to Nikitin (1999). Total $\mathrm{N}\left(\mathrm{N}_{\text {tot }}\right)$ content was determined by the Kjeldahl method using spectrophotometric measure procedure at the wavelength of $655 \mathrm{~nm}$. The content of total $\mathrm{P}\left(\mathrm{P}_{\text {tot }}\right)$ was determined using spectrophotometric measure procedure at the wavelength of $430 \mathrm{~nm}$ and content of total $\mathrm{K}\left(\mathrm{K}_{\mathrm{tot}}\right)$ using flame atomic absorption spectroscopy measurement after wet digestion procedure with sulphuric acid. Plant available contents of phosphorus and potassium were measured by the same procedures though after extraction according Egner-Riehm-Domingo (A-L) method. Stratification ratios were calculated from soil properties at 0-10 $\mathrm{cm}$ divided by those at $20-30 \mathrm{~cm}$.

The statistical evaluation of the data was performed using SAS Enterprice 7.1 software package. The experimental data for all soil parameters were reported as mean from three replicates from the years 2016-2017, and were statistically processed by one-way analysis of variance (ANOVA) procedure. Significant differences among treatment averages were assessed by Fisher's protected (LSD) test with 95\% probability level ( $\mathrm{p} \leq 0.05$ ).

\section{Results and discussion}

The data presented in Table 1 shows that the reduction of tillage intensity had no obvious effect on soil pH. However, reduced tillage combined with additional measures increased soil $\mathrm{pH}$, and only the use of lime sludge significantly increased soil $\mathrm{pH}$ in all soil layers compared to DP treatment. This measure was used three times during the period 2006-2014 to improve soil physical properties and structure, but the soil acidity in the plough layer reached the level of neutral and slightly alkaline soils $(\mathrm{pH}=7.2$ ) and the upper value of the optimum $\mathrm{pH}$ range for agricultural crops (Velykis and Satkus, 2018). The residual effect of lime sludge without further insertion was investigated in this research.

Reduced tillage and applications of organic and inorganic amendments, except for the SP treatment, had a significant effect on the SOC content, compared with control DP treatment (Table 1) in the upper soil layer. DP resulted in the lowest SOC content (12.82 $\mathrm{g} \mathrm{kg}^{-1}$ ) in 0-10 cm layer; meanwhile $\mathrm{PT}+\mathrm{GM}$ resulted in the highest SOC content $-14.85 \mathrm{~g} \mathrm{~kg}^{-1}$. Under the influence of the SOC amount in the $0-10 \mathrm{~cm}$ layer, the treatments can be arranged in the following sequence: $\mathrm{PT}+\mathrm{GM}>\mathrm{NT}+\mathrm{WM}>$ $\mathrm{PT}+\mathrm{LS}>\mathrm{PT}>\mathrm{ST}>\mathrm{DP}$. Incorporation of amendments of different origin in combination with reduced tillage had a more noticeable effect than just reduction of tillage. SOC content in 10-20 and $20-30 \mathrm{~cm}$ soil layers was significantly lower in all reduced tillage treatments compared to DP (except for SP treatment in 10-20 cm layer) due to accumulation of plant residues on the soil surface and their slow degradation. The sustainability of the soil ecosystem is illustrated by the stratification of the SOC in a vertical profile, i.e. the ratio between the SOC content in the 
of 0-10 and 20-30 cm layers. Scientists from different countries stated that the stratification ratio of SOC from 1.5 and more describes the good quality of the soil plough layer (Franzluebbers, 2002; Yang et al., 2008; Liaudanskiene et al., 2010). According to our research, the stratification ratio of SOC in the PT+LS and $\mathrm{NT}+\mathrm{WM}$ treatments was 1.69 , and in $\mathrm{PT}+\mathrm{GM}-1.8$, while in $\mathrm{DP}$ it was only 1.22 .

Nitrogen $(\mathrm{N})$ is known to be the most limiting element for plant growth in the temperate climate. The main reservoir of $\mathrm{N}$ in soil is SOM, and $\mathrm{N}_{\text {tot }}$ content strongly correlated with SOC content (Tripolskaja and Šidlauskas, 2010; Rutkowska and Pikuła, 2013). The distribution of $\mathrm{N}_{\text {tot }}$ in different soil layers is analogous to the distribution of SOC. Reduced tillage and applications of amendments increased the amount of $\mathrm{N}_{\text {tot }}$ in 0-10 cm layer, but substantially more $\mathrm{N}_{\text {tot }}$ was found only in PT+GM and NT+WM treatments respectively 1.77 and $1.81 \mathrm{~g} \mathrm{~kg}^{-1}$, compared to $1.55 \mathrm{~g}$ $\mathrm{kg}^{-1}$ in DP. This increase was determined probably by the high amount of plant residues from the green manure and mulch. The post-harvest catch crops for green manure and aboveground biomass of catch crops for mulching are a source of organic matter that mineralizes and forms mobile $\mathrm{N}$ compounds, which are fixed in soil organic-mineral complexes. The lower compared with SOC stratification ratios of $\mathrm{N}_{\text {tot }}$, which ranges from 1.11 in DP to 1.37 in $\mathrm{PT}+\mathrm{GM}$, can be explained by the fact that ammonium and nitrate compounds formed by mineralization are very mobile and moving down the soil profile, while the C compounds are less mobile.

Carbon and nitrogen are essential elements describing the status of the soil, especially their proportion called $\mathrm{C} / \mathrm{N}$ ratio. The intensity of SOM decomposition and its nature in the soil are determined by the $\mathrm{C} / \mathrm{N}$ ratio, and this relationship determines the SOM's efficiency to improve the soil structure and, at the same time, promotes $\mathrm{C}$ sequestration. The high $\mathrm{C} / \mathrm{N}$ ratio determines the long turnover time of SOM and improves soil aggregation (Hagedorn et al., 2003), while the low $\mathrm{C} / \mathrm{N}$ ratio shows that SOM is rapidly degradable and its effect on soil structure improvement is minimal. It is accepted that the optimal $\mathrm{C} / \mathrm{N}$ ratio is around 10 . We found $\mathrm{C} / \mathrm{N}$ ratio ranged from 8.02 to 8.77 in the upper $0-10 \mathrm{~cm}$ soil layer, and from 6.35 to 7.55 - in the bottom $20-30 \mathrm{~cm}$ layer (Table 1 ). The $\mathrm{C} / \mathrm{N}$ ratio decreased with depth in clay loam soil, and this trend indicates absorption of $\mathrm{N}$ by clay particles in the deeper layers. Moreover, this is in line with Brady and Weil's (2010) findings that $\mathrm{C} / \mathrm{N}$ ratio in arable surface commonly ranges from 8 to 15 , and is generally lower within soil profile. The $\mathrm{C} / \mathrm{N}$ ratio was higher in $\mathrm{PT}+\mathrm{LS}$ and $\mathrm{PT}+\mathrm{GM}$ treatments compared to DP, therefore, it can be stated that the insertion of lime sludge and green manure contributed to the improvement of soil structure.

Table 1

Soil pH, organic carbon and total nitrogen content (mean data 2016-2017)

\begin{tabular}{|c|c|c|c|c|c|}
\hline \multirow{2}{*}{ Treatment } & \multirow{2}{*}{ Layer, cm } & \multirow{2}{*}{$\mathrm{pH}$} & SOC & $\mathrm{N}_{\text {tot }}$ & \multirow{2}{*}{$\mathrm{C} / \mathrm{N}$} \\
\hline & & & \multicolumn{2}{|l|}{$\mathrm{g} \mathrm{kg}^{-1}$} & \\
\hline \multirow{3}{*}{$\begin{array}{l}\text { Deep ploughing } \\
\text { (DP) }\end{array}$} & $0-10$ & 6.0 & 12.8 & 1.5 & 8.3 \\
\hline & $10-20$ & 6.2 & 12.9 & 1.5 & 8.1 \\
\hline & $20-30$ & 6.3 & 10.4 & 1.3 & 7.5 \\
\hline \multirow{3}{*}{$\begin{array}{l}\text { Shallow ploughing } \\
\text { (SP) }\end{array}$} & $0-10$ & 6.0 & 13.3 & 1.6 & 8.2 \\
\hline & $10-20$ & 6.2 & 12.6 & 1.5 & 8.2 \\
\hline & $20-30$ & 6.4 & 8.7 & 1.3 & 6.7 \\
\hline \multirow{3}{*}{$\begin{array}{l}\text { Ploughless tillage } \\
\text { (PT) }\end{array}$} & $0-10$ & 6.0 & 13.6 & 1.6 & 8.3 \\
\hline & $10-20$ & 6.2 & 11.9 & 1.5 & 7.8 \\
\hline & $20-30$ & 6.3 & 9.8 & 1.3 & 7.1 \\
\hline \multirow{3}{*}{$\begin{array}{l}\text { Ploughless tillage with lime sludge } \\
(\mathrm{PT}+\mathrm{LS})\end{array}$} & 0-10 & 7.0 & 14.4 & 1.6 & 8.7 \\
\hline & $10-20$ & 7.1 & 12.1 & 1.5 & 7.7 \\
\hline & $20-30$ & 6.7 & 8.5 & 1.3 & 6.5 \\
\hline \multirow{3}{*}{$\begin{array}{l}\text { Ploughless tillage with green manure } \\
(\mathrm{PT}+\mathrm{GM})\end{array}$} & $0-10$ & 6.2 & 14.8 & 1.7 & 8.4 \\
\hline & $10-20$ & 6.4 & 12.2 & 1.5 & 7.7 \\
\hline & $20-30$ & 6.6 & 8.2 & 1.2 & 6.3 \\
\hline \multirow{3}{*}{$\begin{array}{l}\text { No-tillage with winter mulch } \\
(\mathrm{NT}+\mathrm{WM})\end{array}$} & 0-10 & 6.2 & 14.4 & 1.8 & 8.0 \\
\hline & $10-20$ & 6.3 & 11.9 & 1.5 & 7.7 \\
\hline & $20-30$ & 6.5 & 8.5 & 1.2 & 6.8 \\
\hline \multirow{2}{*}{$\mathrm{LSD}_{0.05}$} & $0-10$ & 0.2 & 0.8 & 0.1 & \\
\hline & $10-20$ & 0.1 & 0.5 & 0.1 & \\
\hline
\end{tabular}


Soil $\mathrm{P}_{\text {tot }}$ is major indicator of soil fertility and quality, because phosphorus plays a key role in plant metabolism, structure and energy transformation. Since intensive tillage promotes the destruction of SOM, the formed bonds between SOM and P or P and clay-organic complexes are destroyed, and this significantly decreases the amount of $\mathrm{P}_{\text {tot }}$ in soil - the lowest amount in 0-10 cm layer was determined in DP $\left(0.55 \mathrm{~g} \mathrm{~kg}^{-1}\right)$ (Table 2). Higher content of $P_{\text {tot }}$ in the $0-10 \mathrm{~cm}$ layer was governed by the influence of SOC on P sorption process; as the SOC content decreases, the amount of $\mathrm{P}_{\text {tot }}$ decreases as well (Debicka et al., 2016). SOC is that soil constituent which increased $P$ binding and restricted $P$ leaching. The application of green manure and mulch as well as lime sludge significantly increased the content of $\mathrm{P}_{\text {tot }}$ in the upper soil layer. Some researchers have identified a tendency of $\mathrm{P}_{\text {tot }}$ content decrease with depth (Fotyma et al., 2013; Jokubauskaite et al., 2015; Debicka et al., 2016), and our results have confirmed this. This distribution is determined by the poor mobility of phosphorus compounds due to the large reactivity of phosphate ions to soil constituents. The accumulation of $\mathrm{P}_{\text {tot }}$ was influenced not only by SOC, but also by other specific properties such as soil $\mathrm{pH}$. The data suggests that accumulation of $\mathrm{P}_{\text {tot }}$ in the 0-10 cm layer depends on the soil acidity: $\mathrm{P}_{\text {tot }}$ content was higher in soil with $\mathrm{pH}_{\mathrm{KCl}}$ level of $7.04(\mathrm{PT}+\mathrm{LS}), 6.29(\mathrm{PT}+\mathrm{GM})$ and 6.22 (NT+WM) compared to $\mathrm{pH} 6.07$ in DP.
While the large proportion of $\mathrm{P}_{\text {tot }}$ in soil is more or less strongly related by soil minerals or SOM, the mobility of $\mathrm{P}$ compounds is ten time less than mobility of $\mathrm{N}$ or $\mathrm{K}$ compounds due to the large reactivity of phosphate ions. It is known that the higher solubility and plant availability of $\mathrm{P}$ compounds occurs in slightly acidic or nearly to neutral soils. This is confirmed by our results; the highest amount of plant available $\mathrm{P}\left(\mathrm{P}_{2} \mathrm{O}_{5}\right)$ content was determined in PT+LS treatment in 0-10 cm layer, whose $\mathrm{pH}$ reached a neutral reaction (7.04).

Potassium (K) is the only essential plant nutrient that is not a constituent of any plant parts, but this element plays a vital role in plant water and energy relations, translocations of assimilates, photosynthesis, protein and starch synthesis and enzyme activation etc. The major source of $\mathrm{K}$ for plants in soils is from clay minerals (Barre et al., 2008; Velde and Baree, 2010). The average concentration of $\mathrm{K}_{\text {tot }}$ in mineral soils is $1.4 \%$, ranging between 0.1 and 4\% (Scherer et al., 2003; Fotyma et al., 2013). Our study indicates that the $\mathrm{K}$ content in clay loam soil varied from 0.9 to $1.04 \%$. Irrespective of the applied tillage and additional measures, the topsoil showed lower $\mathrm{K}_{\text {tot }}$ that $20-30 \mathrm{~cm}$ soil layer indicating pedochemical nature of $\mathrm{K}$ in soil.

Only a small part of $\mathrm{K}$ is present in a form readily available for plant uptake, usually about $1-2 \%$ of the $\mathrm{K}_{\text {tot }}$ (Scherer et al., 2003), in our case plant available potassium $\left(\mathrm{K}_{2} \mathrm{O}\right)$ is about

Table 2

Total and plant available phosphorus and potassium content in soil (mean data 2016-2017)

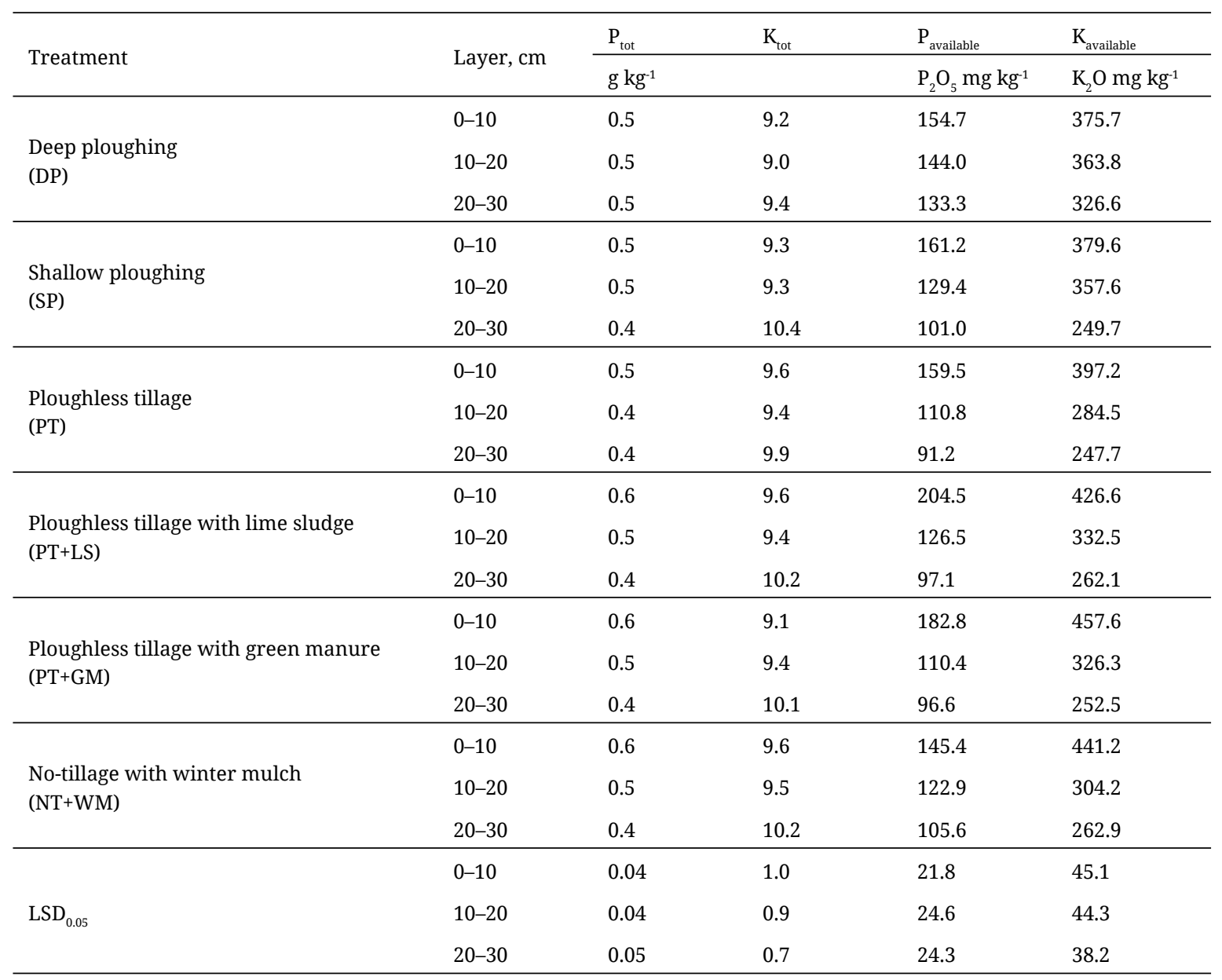


$2 \%$. The highest amounts of $\mathrm{K}_{2} \mathrm{O}$ were found in $0-10 \mathrm{~cm}$ layer in treatments with additional improvement measures 426.6 in $\mathrm{PT}+\mathrm{LS}, 457.6$ in $\mathrm{PT}+\mathrm{GM}$, and $441.2 \mathrm{mg} \mathrm{kg}^{-1}$ in NT+WM, and these amounts were significantly higher compared to $375.4 \mathrm{mg} \mathrm{kg}^{-1}$ in DP treatment.

\section{Conclusions}

1. Ploughless tillage and its combinations with lime sludge and green manure as well as mulch without autumn tillage significantly increased soil organic carbon content in the 0-10 cm layer but decreased in 10-20 and 20-30 cm layers.

2. All investigated reduced tillage systems increased total nitrogen content in 0-10 cm layer but only the influence of cover crops for green manure and mulch was significant.

3. Incorporation of lime sludge, green manure and mulch led to a substantial increase in total and plant available phosphorus, plant available potassium content in $0-10 \mathrm{~cm}$ soil layer.

4. The stratification of organic carbon and macronutrients in clay loam was the least with deep ploughing.

\section{Acknowledgments}

The research was conducted under the research programme "Productivity and Sustainability of Agricultural and Forest Soils" implemented by Lithuanian Research Centre for Agriculture and Forestry.

\section{References}

Baree, P., Velde, B., Fontaine, C., Catel, N., Abbadie, L., 2008. Which 2:1 clay minerals are involved in the soil potassium reservoir? Insights from potassium addition or removal experiments on the three temperate grassland soil clay assemblages. Geoderma 146, 216-223. https://DOI: 10.1016/j.geoderma.2008.05.022

Blanco-Canqui, H., Lal, R., 2008. No-tillage and soil-profile carbon sequestration: an on-farm assessment. Soil Science Society of America Journal 72, 693-701. https://DOI: 10.2136/sssaj2007.0233

Brady, N.C., Weil, R.R., 2010. Elements of the Nature and Properties of Soils. Pearson Education, Prentice Hall, New Jersey.

Brovkin, V., Boysen, L., Arora, V.K., Boisier, J.P., Cadule, P., Chini, L., Claussen, M., Friedlingstein, P., Gayler, V., van den Hurk, B.J.J.M., Hurtt, G.C., Jones, C.D., Kato, E., de Noblet-Ducoudre, N., Pacifico, F., Pongratz, J., Weiss, M., 2013. Effect of anthropogenic land-use and landcover changes on climate and land carbon storage in cmip 5 projections for the twenty-first century. Journal of Climate 26, 6859-6881. https://DOI: 10.1175/JCLI-D-12-00623.1

COM 231. 2006. Communication from the Commission to the Council, the European Parliament, the European Economic and Social Committee and the Committee of the Regions - Thematic Strategy for Soil Protection. Commission of the European Communities, Brussels

COM 46. 2012. Report from the Commission to the European Parliament, the Council, the European Economic and Social Committee and the Committee of the Regions - The Implementation of the Soil Thematic Strategy and ongoing activities. Commission of the European Communities, Brussels

Debicka, M., Kosowicz, A., Weber, J., Jamroz, E., 2016. Organic matter effects on phosphorus sorption in sandy soils. Archives of Agronomy and Soil Science 62, 840-855. https://DOI: 10.1080/03650340.2015.10 83981

Fotyma, M., Ochal, P., Łabętowicz, J., 2013. Potassium in soils of glacial origin. In: M.C. Hernandez Soriano (ed.). Soil Processes and Current Trends in Quality Assessment. Intech Open, 205-228. https://DOI: 10.5772/52005

Franzluebbers, A.J., 2002. Soil organic matter stratification ratio as an indicator of soil quality. Soil and Tillage Research 66, 95-106. https:// DOI: 10.1016/S0167-1987(02)00018-1

Ghani, A., Dexter, M., Perrott, K.W., 2003. Hot-water extractable carbon in soils: a sensitive measurement for determining impacts of fertilisation, grazing and cultivation. Soil Biology and Biochemistry 35, 1231-1243. https://DOI: 10.1016/S0038-0717(03)00186-X

Hagedorn, F., Spinnler, D., Bundt, M., Blaser, P., Siegwolf, R., 2003. The input and fate of new $\mathrm{C}$ in two forest soils under elevated $\mathrm{CO} 2$. Global Change Biology 9, 862-872. https://DOI: 10.1046/j.13652486.2003.00638.x

Hontoria, C., Gomez-Paccard, C., Mariscal-Sancho, I., Benito, M., Perez, J., Espejo, R., 2016. Aggregate size distribution and associated organic $\mathrm{C}$ and $\mathrm{N}$ under different tillage systems and Ca-amendment in a degraded Ultisol. Soil and Tillage Research 160, 42-52. https://DOI: 10.1016/j.still.2016.01.003

Jokubauskaitė, I., Karčauskienė, D., Antanaitis, Š., Mažvila, J., Šlepetienė, A., Končius, D., Piaulokaitè-Motuzienè, L., 2015. Zemdirbyste-Agriculture 102(3), 251-256. https://DOI: 10.13080/z-a.2015.102.032

Liaudanskienè, I., Šlepetienè, A., Velykis, A., 2010. Changes of physically unprotected soil organic matter carbon content due to sustainable tillage (in Lithuanian). Vagos 88(41), 38-43.

Nikitin, B.A., 1999. Methods for soil humus determination. Agro Chemistry 3(2), 156-158.

Ogle, S.M., Breidt, F.J., Paustian, K., 2005. Agricultural management impact on soil organic carbon storage under moist and dry climatic conditions of temperate and tropical regions. Biogeochemistry 72, 87-121. https://DOI: 10.1007/s10533-004-0360-2

Rutkowska, A., Pikuła, D., 2013. Effect of crop rotation and nitrogen fertilization on the quality and quantity of soil organic matter. In: M.C. Hernandez Soriano (ed.). Soil Processes and Current Trends in Quality Assessment. Intech Open 249-267. https://DOI: 10.5772/53229

Saroa, G.S., Lal, R., 2003. Soil restorative effects of mulching on aggregation and carbon sequestration in a Miamian soil in Central Ohio. Land Degradation and Development 14, 481-493. https://DOI: 10.1002/ ldr.569

Slepetiene, A., Liaudanskiene, I., Slepetys, J., Velykis, A., 2010. The influence of reduced tillage, winter crops and ecologically managed longterm mono- and multi-component swards on soil humic substances. Chemistry and Ecology 26, 97-109. https://DOI: 10.1080/02757540.20 10.501029

Scherer, H.W., Godbach, H.E., Clemens, J., 2003. Potassium dynamics in the soil and yield formation in a long-term field experiment. Plant, Soil and Environment 49(12), 531-535. https://DOI: 10.17221/4189PSE

Torkashvand, A.M., Bizhannia, A., Mavajpour, M., Haghighat, N., 2011. The use of a by-product of paper industry in reclamation of berrycultivated soils. Life Science Journal 8, 658-661.

Tripolskaja L., Šidlauskas G., 2010. The influence of catch crops for green manure and straw on the infiltration of atmospheric precipitation and nitrogen leaching (in Lithuanian). Zemdirbyste-Agriculture 97(1), 83-92.

van Groenigen, K.J., Bloem, J., Bååth, E., Boeckx, P., Rousk, J., Bode, S., Forristal, D., Jones, M., 2010. Abundance, production and stabilization of microbial biomass under conventional and reduced tillage. Soil Biology and Biochemistry 42, 48-55. https://DOI: 10.1016/ j.soilbio.2009.09.023

von Lützow, M., Kögel-Knabner, I., Ekschmitt, K., Flessa, H., Guggenberger, G., Matzner, E., Marschner, B., 2007. SOM fractionation meth- 
ods: relevance to functional pools and to stabilization mechanisms. Soil Biology and Biochemistry 39, 2183-2207. https://DOI: 10.1016/ j.soilbio.2007.03.007

Viaud, V., Angers, D.A., Parnaudeau, V., Morvan, T., Menasseri-Aubry, S., 2011. Response of organic matter to reduced tillage and animal manure in a temperate loamy soil. Soil Use and Management 27, 84-93. https://DOI:10.1111/j.1475-2743.2010.00314.x

Velde, B., Barre, P., 2010. Soils, Plants and Clay Minerals. Springer. https:// DOI 10.1007/978-3-642-03499-2
Velykis, A., Satkus, A., 2018. The impact of tillage, Ca-amendment and cover crop on the physical state of a clay loam soil. Zemdirbyste-Agriculture 105(1), 3-10. https:// DOI 10.13080/z-a.2018.105.001

Yang, X.M., Drury, C.F., Reynolds, W.D., Tan, C.S., 2008. Impact of long term and recently imposed tillage practices on the vertical distribution of soil organic carbon. Soil and Tillage Research 100, 120-124. https:// DOI: 10.1016/j.still.2008.05.003 